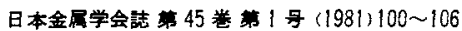

\title{
定時間積分-発光分光分析法による工具鋼と高速度鋼の 検量線の1元化と補正法の検討*
}

$\begin{array}{lllll}\text { 大河内 } & \text { 春 } 乃^{* *} & \text { 高 } & \text { 橋 } & \text { 征** } \\ \text { 鈴 } & \text { 木 俊 一* } & \text { 須 } & \text { 藤 } & \text { 恵美子** }\end{array}$

\author{
J.Japan Inst.Metals,Vol.45, No.1(1981), pp.100 106 \\ Fixed Time Integration-Emission Spectrochemical Analysis of Tool Steels \\ and High Speed Steels by Unified Calibration Curves and Study \\ of a Correction Method
}

Haruno Okochi**, Katsuyuki Takahashi**, Shunichi Suzuki** and Emiko Sudo**

Unification of calibration curves for analysing micro-amounts of elements (N,S,C, Mo, Si, $\mathrm{Ni}, \mathrm{Mn}, \mathrm{Cu})$ in tool steels and high speed steels was investigated. Iron contents in them vary from ca. 65 to $95 \%$, so that classified calibration curves or correction of amounts of iron are necessary in the case of the internal standard method, while satisfied results were obtained by the fixed time integration method.

For correction of interfering elements, iron base binary alloys were used for tool steels and multiple alloys were needed for high speed steels. Further, in order to decide coefficients of correction for high speed steels, the use of multiple regression analysis was investigated, using the calibration curves for only tool steels corrected with binary alloys, high speed steels were determined and the differences between the analytical values and the standared ones were used for calculation. Consequently, coefficients of correction were decided by using binary alloys for tool steels and by multiple regression analysis for high speed steels.

The relation between sensitivities of analysis and coefficients of correction was also examined. As sensitivities the gradients of the calibration curves were chosen, and when the calibration curves were not straight, the gradients of regression lines in the trace region were used. The relation of hyperbola was observed between them; the larger the sensitivities the smaller became the change of coefficients of correction, and the lesser the sensitivities the smaller became the number of interfering elements.

In tool steels, emission intensities were not affected by amounts of carbon from 0.2 to $1.4 \%$, while they decreased in larger amounts of carbon (ca. 1.3\%) in high speed steels.

Tool steels and high speed steels were analysed with unified calibration curves. According to the results of the $F$-test, it was not concluded that there were differences in variance between tool steels and high speed steels and the accuracies of analysis were sufficiently high.

(Received November 7,1980)

\section{I. 舶 言}

著者らはすでに，定時間積分法を主成分元素が試料間で 大きく変化するニッケル基超耐熱合金 ${ }^{(1)}$ ，拉よび高速度 鋼(2) 適用儿，内摽準法では，当然，層別検量線や鉄量 (またはニッケル量)補正が必要な所，検量線の 1 元化に良 好な結果を得た。

本報に打いては，主成分元素量が試料間で，さらに大き く変化する工具龬と高速度鋼の検量線 る，微量元素に関し ては，1元化の可能性が予測さ礼研究を行った，その結 果, N,S C, Mo, Si, Ni, Mn，Cu の定量に良好な検量線が 作成された。
発光分光分析において，共存元素の影響の補正は重要な 問題であり，多くの研究が発表されている．最近，鉄基 2 元系試料火よる検討がかなり行われ，有用な知見が得られ ている(3) (8). 遠藤ら ${ }^{(4)}$ は 2 元系および 3 元系試料により 相乗干涉の研究を行い興味ある結果を報告している。

通常，実際の分析に際しては，補正式を求めた時之同一 測定条件で定量が行われる。また，各所で算出した補正俰 数が統計処理されている場合す范る(3). 測定条件が変化し た場合，補正係数がどのように变化するか関しては，い まだ知見が得られていない，本報に批いては，測定感度と 補正係数の関連について詳細に検討した結果, 注目すべき 結論が得られた。 
高速度鋼に扎いて近接線の影響を検討する場合，鉄基 2 元系試料は不適当で，高速度鋼に類似した多元系試料を用 いる必要があることを前報(2)で報告した。本報に捣いて は，鉄基 2 元系試料で補正した工具鋼のみの検量線で高速 度鋼を定量し，表示值との差より重回㷌分析で補正係数 を算出する方法を試み満足すべき結果を得た，以上の方法 は，多元系試料中以含ま礼る目的定量元素のブランク值の 問題がなく，興味深い方法と思われる。

\section{II. 実 験 方 法}

使用した発光分光分析装置，再溶解装置および発光分光 分析条件は前報(2)の通りである。

使用した標準試料は日本鉄鋼標準試料機器分析用工具鍓 (JSS 600 605-1,6) と高速度鋼(JSS 606〜611-3,5) 拉よび NBS SRM D837，838，840，841である。再溶解試料の作 製に際しては，日本鉄銿標準試料化学分析用を用いた。近 接線の影響の検討には，日本鉄鋼標準試料鉄基 2 元系試料 を使用した。

検量線の多項式近似，高速度鋼の補正係数の重回帰分析 拉よび $F$ 検定等はすべて電算機を使用した。

\section{III． 統一検量線の試み}

始めに, 工具鋼(鉄量：約 90 95\%), 高速度鋼(鉄量： 約 65〜85\%)扣よび比較のために，鉄量が 95〜97\%と多い 強靶鋼(JSS 500 505)を同時に定時間積分法て測定し，検 量線の作成を試みた。Fig.1 亿硫黄 (I $180.73 \mathrm{~nm}$ ) 女窒素 (I $174.53 \mathrm{~nm}$ )の例を示す。共存元素の影響は鉄基 2 元系
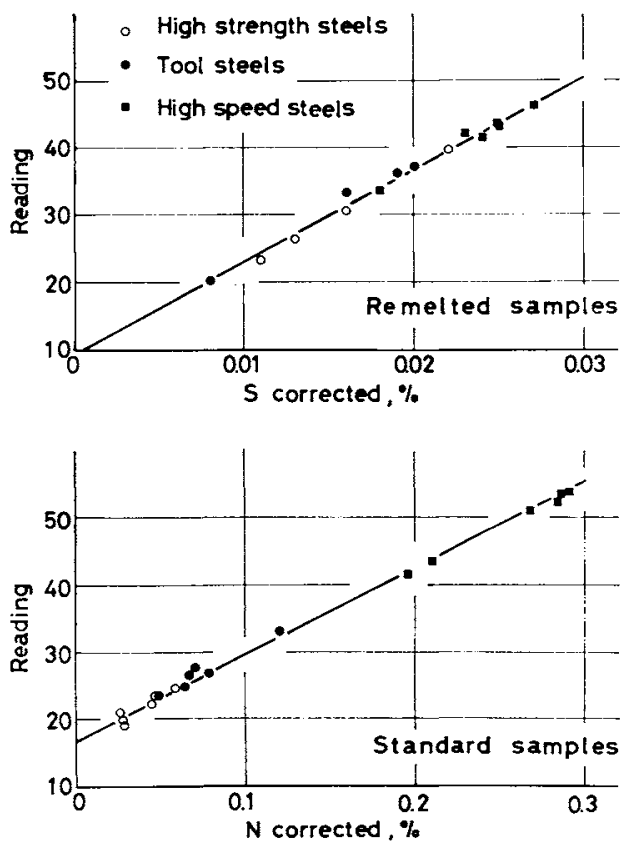

Fig.1 Unification of calibration curves of sulfur or nitrogen.

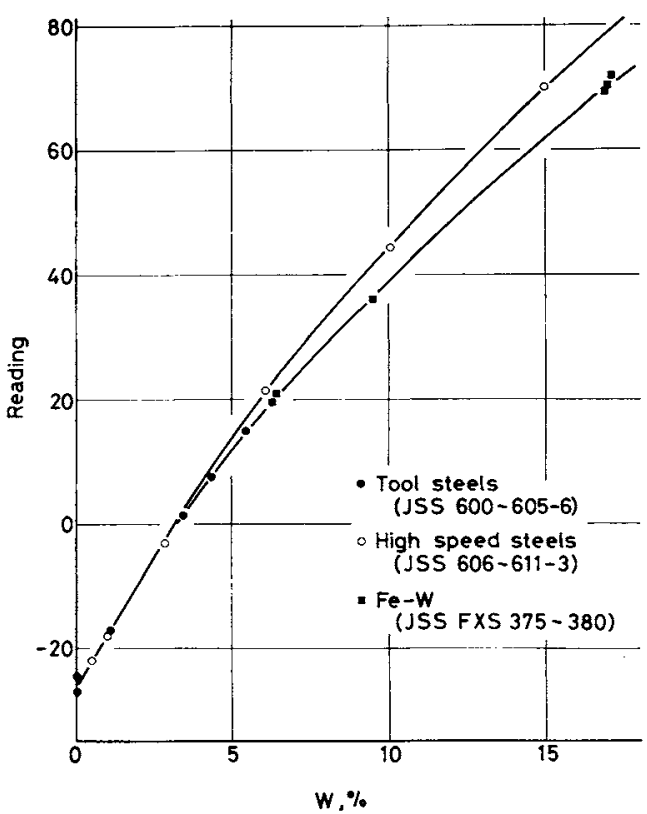

Fig.2 Calibration curve of tungsten. 試料を用いて補正した。硫黄の場合は $\mathrm{Mn}, \mathrm{V}, \mathrm{W}, \mathrm{Mo}, \mathrm{Cr}$ ， $\mathrm{Ni}$ に上る妨害を補正し，窒素の場合は，Mn, Mo, W, Ni， V,Ti，Cr飞関して補正を行った。なお，硫黄の分析は， 高媯波溶解遠心鋳造法による再溶解試料を使用した。本試 料は機器分析用標準試料に比較し，硫化マンガンによる偏 析がなく，分析精度が良好となる(2)．雨者共，かなり良く 一本の检量線上に乗ることが分る。

次に，高含有量成分の一例として，タングステン(II $220.45 \mathrm{~nm}$ ) の検量線を Fig.2 亿示す. 比較として, Fe-W 2 元系試料(JSS FXS 375 380) 同時に測定した。本測 定条件では，近接線の影響がなく ${ }^{(2)}$ ，補正の必要はない。 高含有量領域で，2元系試料と高速度鋼との間に大きな開 きが見られる.化学組成と電極消耗量の間に相関があるこ とが知られている ${ }^{(9)}$. Si，Cr，Mo 等は消耗量を減ずる効果 を持つ，検量線の開きの原因として，消耗量の差が考察さ れる。一方，微量域では，両者はほとんど一致している。 消耗量による差の絶対值が少なくなり，定量值の桁数が減 少すれば，䛊差範囲となることが考兄られる。

以上の事実上り，工具鋼と高速度鋼の微量元素に関して は, 統一検量線作成の可能性が予想され検討を行った。

\section{IV，共存元素の影䈉}

高速度鋼は内標隼法では鉄量の影響を大きく受けるが， 定時間積分法では影響を受けない、(2).工具銅の鉄量变化は 約 90 95\% で高速度鋼に比較すると小さいが，内標準法 之定時間積分法の比較を行った．他の合金元素量は一定 で，鉄量が 88〜96\% をで変化する工具鋼を高周波溶解遠 心鋳造機で作製Lた.JSS 603-3(化学分析用) $8.966 \mathrm{~g}$ 亿鉄 を変化して加元，変化分は金属ニッケルなたはクロム(Fe- 
Cr 合金として添加)で補正し， 1 個 $23 \mathrm{~g}$ の試料を 5 種類 ず作製した，発光分光分析した結果， N,P,Ni, Mn, V 等は，内標準法では鉄量の影響を示したが，定時間積分法 では一定值を与えた。さらに，工具鋼と高速度鋼を同一検 量線で測定する場合，鉄量変化は 65 〜 $95 \%$ となり，内標 準法では，当然，鉄量補正を必要とする。

前報 ${ }^{(2)}$ に拈いて，高速度鋼に和ける共存元素の影響は多 元系試料で娭討する必要を報告した，今回，徽量元素の定 量に際し，改めて補正法を検討した。例として：ニッケル (II $231.60 \mathrm{~nm}$ ) 测定におけるコバルトの影響について謂べ た.ニッケル $0,0.050,0.11 \%$ に対し，それぞれ，コバル ト， $0,2,5,7,10 \%$ 含有する 2 元系ないし 3 元系試料を作 製した。庸材として、ニッケルスポンジ(JMC Spectrographically standardised)，金属コバルト $(99.5 \%)$ ，お よび電解鉄を用い全量 $40 \mathrm{~g}$ とて，0.3\%アルミニウムを

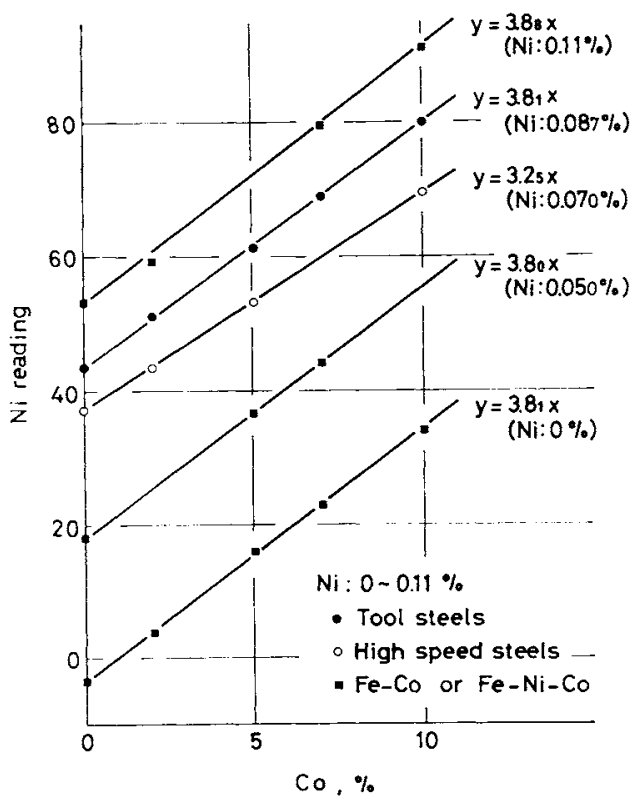

Fig.3 Effect of amounts of cobalt on intensities of nickel.

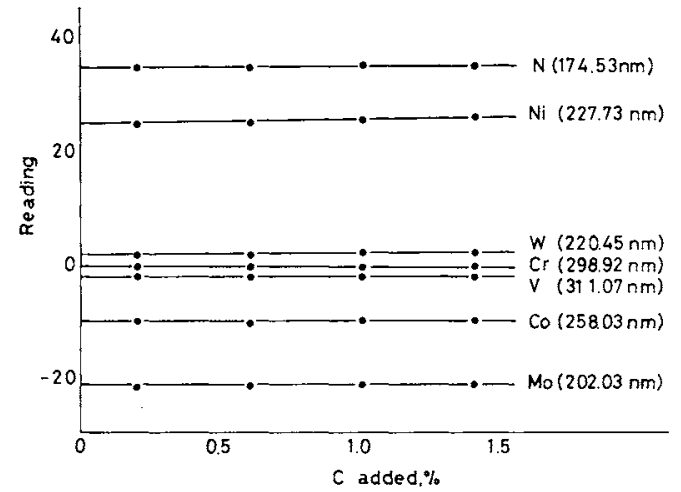

Fig.4 Effect of carbon content in tool steels on intensities.
加え再溶解した，工具鋼および高速度鋼試料としては， JSS 601-5 22.50g，または，JSS 611-2 $22.00 \mathrm{~g}$ にコバル トを0 2.5 g なで変化して加光, 電解鉄を加え全量 25.00 gとして再溶解した。これらの試料の測定結果をFig.3に 示与. 各值線の公配は，高速度鋼の 3.25 以外は約 3.8 と ほぼ一定值を示した，以上の結果より，工具鋼は 2 元系試 料で補正すればよく，高速度鋼の場合は，前報 ${ }^{(2)}$ 通り，多 元系試料の必要を確㤎した。

高速度鋼の場合，高炭素含有試料は発光強度が低下する ため，層別検量線の必要を認めた ${ }^{(2)}$ ．同様の検討を工具鋼 について行った。 工具鋼 JSS 603-5に炭素量調整用とし

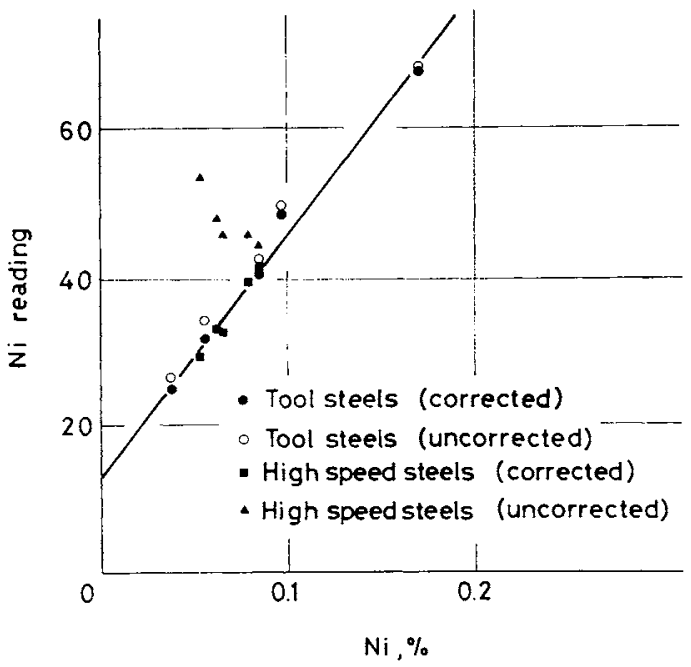

Fig. 5 Calibration curve of nickel.

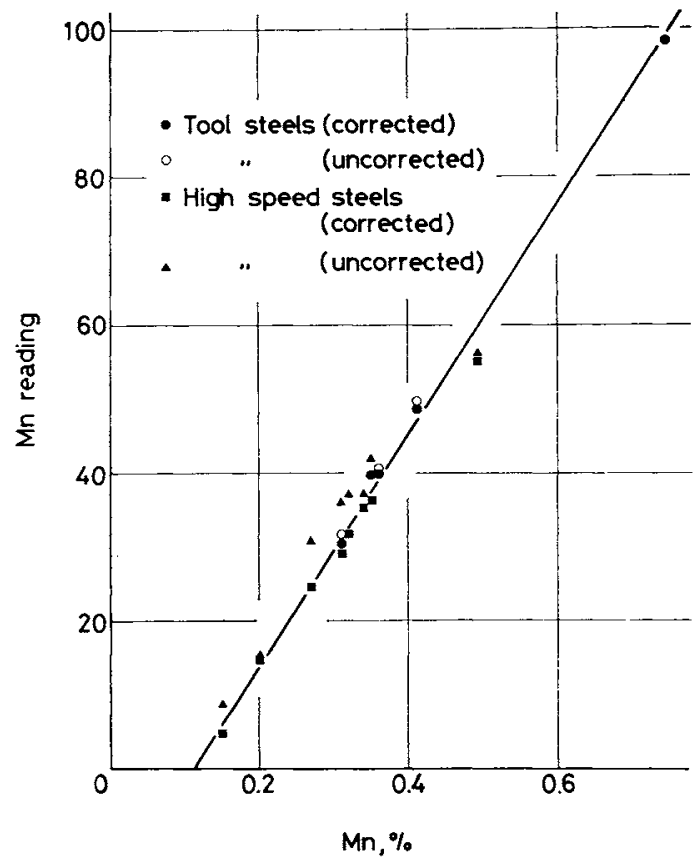

Fig.6 Calibration curve of manganese. 
て, JSS 110-4 (鉄鉄)を変化して加兄，変化分は鉄を添加 し，炭素添加量0.2 1.4\%の試料を作製した。測定の絬 果，Fig.4 示すように，一定の発光強度を示すことが判 明した。

前述の補正法で補正值を求め検量線を作成した。高速度 鋼補正用試料としては，前報(2)で作製した $\mathrm{V}, \mathrm{Mo}, \mathrm{W}, \mathrm{Co}$ 系試料学用いた. 工具鋼の場合は, $\mathrm{Fe}-\mathrm{V}, \mathrm{Mo}, \mathrm{W}, \mathrm{Co}, \mathrm{Cr}$ 采について検討した。 ニッケル(II $231.60 \mathrm{~nm})$ とマンガン (II $293.31 \mathrm{~nm}$ )の検量線の例を Fig.5 と Fig.6亿示す. 標準試料と同時に浿定した 2 元系と多元系試料により，発 光強度の読みを補正している。補正の結果，一直線上儿乗 ることが分る.使用した試料は, JSS 600〜605-6 と JSS 606〜611-5 で, マソガソの場合は,さらに JSS 606 611-3 を追加している。な怙，マンガンの検量線に批いて未補正 の点がない工具鋼は，未補正も補正もほとんど差がないも のである.

\section{V. 測定感度と補正係数}

測定感度のめやすとして，検量線の勾配を取り，3段階 に感度を变光て測定した。横軸涂量線の勾配を取り，縦 軸に 2 元系ない乙多元系試料より求めた妨害元素の影暗の 勾配[発光強度の瞽み/妨害元素量(\%)]をプロットすると， その間炕直線関係があることが見出された。一例として，

Fig.7 亿炭素(I $193.09 \mathrm{~nm}$ )に対するタングステンの妨害 を示した。横軸の切片は 2 元系陚料と多元系陚料で一致し た. 妨害元素汶対方る補正式を $d_{\mathrm{M}}=\alpha \cdot C_{\mathrm{A}}(\%)\left[d_{\mathrm{M}}\right.$ : 定量 元素 $\mathrm{M}$ 誴差 $(\%), \alpha$ : 補正係数, $C_{\mathrm{A}}$ : 妨害元素 $\mathrm{A}$ の濃度

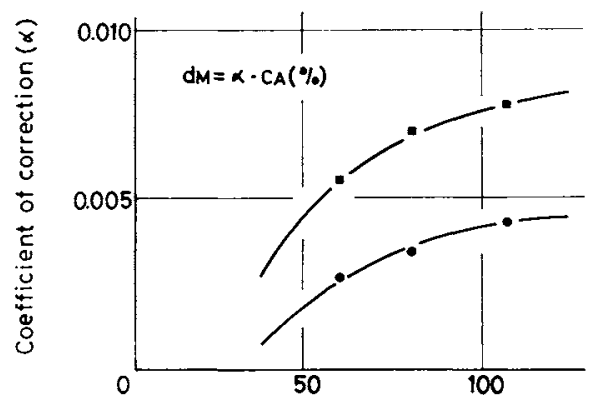

Gradient of calibration curves, reading $/ \%$

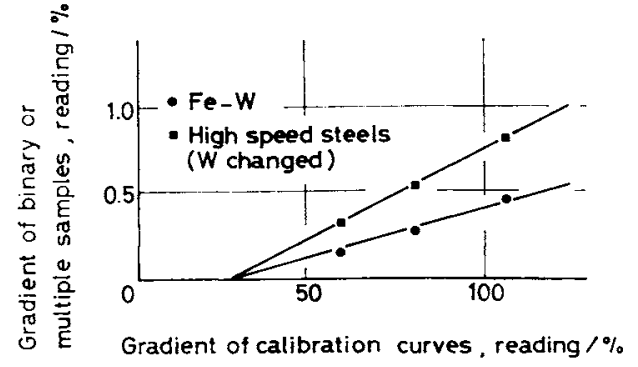

Fig.7 Effect of tungsten on_determination of carbon (I $193.09 \mathrm{~nm}$ ).

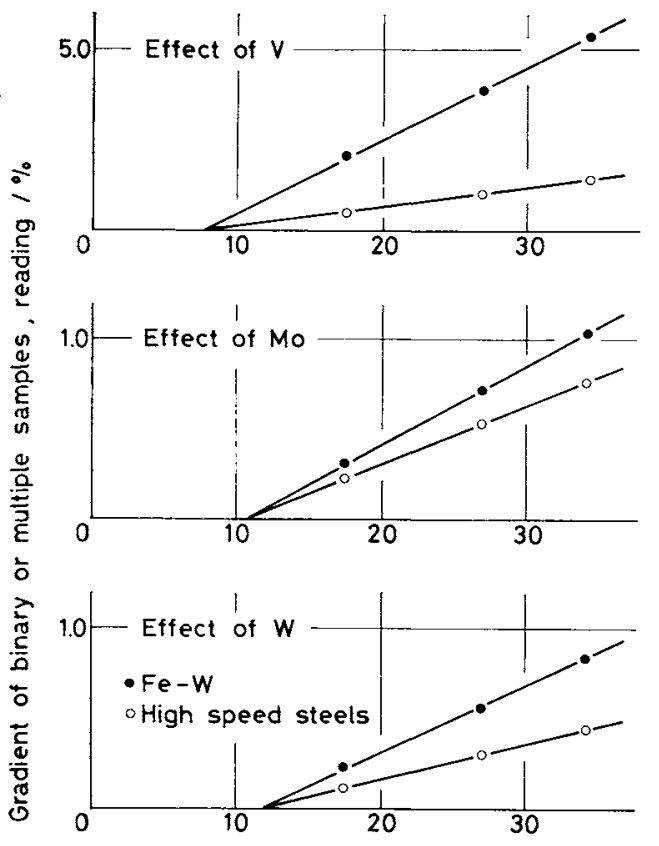

Gradient (trace range) of calibration curves, reading $1 \%$

Fig.8 Effect of interferring elements on determination of chromium (II $298.92 \mathrm{~nm}$ ).

(\%)]とすると，榆量線の勾配と補正係数の間には Fig.7 のよらな双曲線の関係が存在する。補正保数 $\alpha$ は, 検 量 線が直線の場合は[妨害元素の影響の勾配]/[検 量線の勾 配了上り算出され，检量線が曲線の時は，前報(1)(2)の上う に求める。 また, 検量線が曲線の時は, 測定感度のめやす として，定量元素の微量域より求めた 1 次回帰式の公配を 取ることにより，同様の直線関係が得られる。一例とし て,クロム(II $298.92 \mathrm{~nm}$ )の場合を Fig.8亿示す. 一定 の定量元素に打いては，横軸の切片は妨害の程度が大きい ほど原点に近く，妨害が小さい汪ど原点より遠くなる。以 上の検量線とは，前報(1)(2)の上万近接線の影響を補正し た検量線を意味する。な括，測定感度を変えて測定する 場合，記録計の汪济同じ領域で測定し，注意深くデータ処 理する際に，上記の相関が観察された。

\section{VI. 重回帰分析による補正保数の算出}

高速度鋼妨害元素補正用試料は自家製であり，特に微量 定量際してはこ学らら試料中の目的元素量の把握が煩雑 な問題となる．以上の久点を解決するために下記の事を検 討した。すなわち，前記の補正法により統一検量線の作成 が可能であるということを前提として，検量線は鉄基 2 元 系試料で補正した工具鋼のみで作成し，高速度鋼を分析す る. 定量値と表示値との差 $d_{\mathrm{M}}$ より，重回帰分析で補正係 数を算出する．妨害が予想される元素は，2 元系試料の結

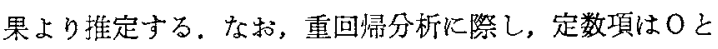
なるように計算し，負の補正係数は妨害はないと仮定し た。 
Multiple regression analysis ( $\mathrm{Si}$ )

\begin{tabular}{|c|c|c|c|c|c|c|c|}
\hline Grad. & Coetf. & of corre & ection & $T-$ & TEST & & 7 \\
\hline c.c. & Mo & W & Co & Mo & W & Co & \\
\hline 107.9 & 0.029 & 0.0046 & 0.0005 & 15.14 & 9.45 & 0.51 & 0.9973 \\
\hline 200.4 & 0.028 & 0.0057 & 0.0017 & 51.43 & 42.35 & 6.26 & 0.9998 \\
\hline 222.0 & 0.028 & 0.0058 & 0.0016 & 66.22 & 54.12 & 7.06 & 0.9999 \\
\hline
\end{tabular}

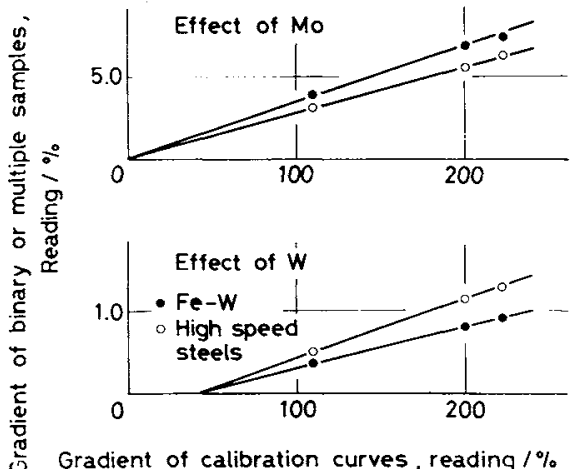

Fig.9 Calculation of coefficient of correction for high speed steels by multiple regression analysis.
一例としてけい素の場合をFig.9亿示す．2元系試料 の測定上り，Mo，W，Co が妨害元素として子想され重回帰 分析を行うと表に示す結果が得られる。使用した陚料は 工具銅 JSS 600 605-6, 高速度鋼 JSS 606 611-5, NBS SRM D 840, 841 で，測定感度を 3 段階に变元た。陚料数 8 , 自由度 4 , 確率 $5 \%$ に拈ける $t$ 分布炕従与確率变数は 2.776 で，公配 107.9 の場合のコバルトの補正係数 0.0005 を除き， $t$ 検定の結果，いずれる有意であると結論された。 重相関係数も十分大きい。これらの数値より，V，で述べ た勾配の関係をプロットすると，Fig.9のように直線関係 が得られ，横軸の切片は 2 元系之一致した。以上の結果よ り，高速度鋼の補正係数は重回帰分析で算出することが可 能であることが判明した。

\section{VII．工具鋼と高速度鋼の分析}

分析に先立ち，工具鋼は鉄基 2 元采試料で，高速度鋼は 重回帰分析で，補正保数を算出した。 その結果をTable 1 に示す。波長表 ${ }^{(10)(11)}$ 火見られる近接線(分析線 $\pm 0.1 \mathrm{~nm}$ (3)）の例を（）内に示した．検討対称にした妨害元素は, 標準訊料中含有量が大きく変化する合金元素，V,Mo, W， $\mathrm{Co}, \mathrm{Cr}$ である。算出に使用した標準試料は Table 2 と同

Table 1 Formulae for correcting interferences.

\begin{tabular}{|c|c|c|c|}
\hline \multirow{2}{*}{$\begin{array}{l}\text { Analytical } \\
\text { lines }(\mathrm{nm})\end{array}$} & \multicolumn{2}{|c|}{ Formulae for correcting interferences } & \multirow{2}{*}{$\begin{array}{l}\text { Examples of neighbouring } \\
\text { spectral lines }( \pm 0.1 \mathrm{~nm})\end{array}$} \\
\hline & Tool steels & High speed steels & \\
\hline NI 174.53 & $\begin{array}{ll}\mathrm{N}=0.0077 & \mathrm{~V}(\%) \\
\mathrm{N}=0.00434 & \mathrm{~W}(\%) \\
\mathrm{N}=0.00188 & \mathrm{Mo}(\%) \\
\mathrm{N}=0.00171 \mathrm{Cr}(\%)\end{array}$ & $\begin{array}{l}\mathrm{N}=0.00386 \mathrm{~W}(\%) \\
\mathrm{N}=0.00210 \mathrm{Mo}(\%) \\
\mathrm{N}=0.00273 \mathrm{Cr}(\%)\end{array}$ & $174.622(\mathrm{Mo})$ \\
\hline S I 180.73 & $\begin{array}{ll}\mathrm{S}=0.00083 & \mathrm{~W}(\%) \\
\mathrm{S}=0.00067 & \mathrm{Mo}(\%) \\
\mathrm{S}=0.00061 & \mathrm{Cr}(\%)\end{array}$ & $\begin{array}{l}\mathrm{S}=0.000848 \mathrm{~W}(\%) \\
\mathrm{S}=0.00116 \mathrm{Mo}(\%) \\
\mathrm{S}=0.000265 \mathrm{Co}(\%)\end{array}$ & $\begin{array}{l}180.763,180.791(\mathrm{Mo}) \\
180.635(\mathrm{Co})\end{array}$ \\
\hline C. $\quad 193.09$ & $\begin{array}{ll}\mathrm{C}=0.0139 & \mathrm{Cr}(\%) \\
\mathrm{C}=0.0063 & \mathrm{Mo}(\%) \\
\mathrm{C}=0.0025 & \mathrm{~W}(\%)\end{array}$ & $\begin{array}{l}C=0.0026 \quad \mathrm{Mo}(\%) \\
\mathrm{C}=0.00805 \mathrm{~W}(\%)\end{array}$ & $\begin{array}{l}192.996(\mathrm{Cr}) \\
193.051,193.098(\mathrm{Mo})\end{array}$ \\
\hline MoII 202.03 & $\mathrm{Mo}=0.0046 \quad \mathrm{~W}(\%)$ & $\mathrm{Mo}=0.00256 \quad \mathrm{~W}(\%)$ & $201.957,202.013(W)$ \\
\hline Si I 212.42 & $\begin{array}{ll}\mathrm{Si}=0.0327 & \mathrm{Mo}(\%) \\
\mathrm{Si}=0.0051 & \mathrm{Cr}(\%) \\
\mathrm{Si}=0.0036 & \mathrm{~W}(\%)\end{array}$ & $\begin{array}{l}\mathrm{Si}=0.0288 \mathrm{Mo}(\%) \\
\mathrm{Si}=0.00559 \mathrm{~W}(\%) \\
\mathrm{Si}=0.00172 \mathrm{Co}(\%)\end{array}$ & $\begin{array}{l}212.484,212.511(\mathrm{Mo}) \\
212.460(\mathrm{~W})\end{array}$ \\
\hline $\mathrm{Ni}$ II 231.60 & $\begin{array}{ll}\mathrm{Ni}=0.0036 & \mathrm{~W}(\%) \\
\mathrm{Ni}=0.0016 & \mathrm{Mo}(\%)\end{array}$ & $\begin{array}{ll}\mathrm{Ni}=0.00093 & \mathrm{~W}(\%) \\
\mathrm{Ni}=0.00009 & \mathrm{Mo}(\%) \\
\mathrm{Ni}=0.00584 & \mathrm{Co}(\%)\end{array}$ & $\begin{array}{l}231.502,231.626(\mathrm{~W}) \\
231.563,231.617(\mathrm{Mo}) \\
231.616,231.686(\mathrm{Co})\end{array}$ \\
\hline $\mathrm{Mn}$ II 293.31 & $\begin{array}{ll}\mathrm{Mn}=0.0048 & \mathrm{~V}(\%) \\
\mathrm{Mn}=0.0044 & \mathrm{Cr}(\%) \\
\mathrm{Mn}=0.0018 & \mathrm{Mo}(\%) \\
\mathrm{Mn}=0.0014 & \mathrm{~W}(\%)\end{array}$ & $\begin{array}{ll}\mathrm{Mn}=0.0028 & \mathrm{Mo}(\%) \\
\mathrm{Mn}=0.00230 & \mathrm{~W}(\%)\end{array}$ & $\begin{array}{l}293.232,293.322(\mathrm{~V}) \\
293.347,293.397(\mathrm{Cr}) \\
293.218,293.320(\mathrm{Mo}) \\
293.221,293.298(\mathrm{~W})\end{array}$ \\
\hline $\mathrm{Cu} I \quad 327.40$ & $\begin{array}{ll}\mathrm{Cu}=0.00064 & \mathrm{Mo}(\%) \\
\mathrm{Cu}=0.00044 & \mathrm{~V}(\%) \\
\mathrm{Cu}=0.00035 & \mathrm{Cr}(\%) \\
\mathrm{Cu}=0.00016 & \mathrm{~W}(\%)\end{array}$ & $\begin{array}{ll}\mathrm{Cu}=0.00478 & \mathrm{~V}(\%) \\
\mathrm{Cu}=0.00023 \mathrm{Cr}(\%) \\
\mathrm{Cu}=0.000498 \mathrm{~W}(\%)\end{array}$ & $\begin{array}{l}327.357,327.418(\mathrm{Mo}) \\
327.302(\mathrm{~V})\end{array}$ \\
\hline
\end{tabular}


Table 2 F-test for differences in variance of analytical results between high speed steels and tool steels.

\begin{tabular}{|c|c|c|c|c|c|c|c|c|c|c|}
\hline & \multirow{2}{*}{$\begin{array}{c}\text { Content } \\
(\%)\end{array}$} & \multirow{2}{*}{$\begin{array}{c}\text { Grad.* } \\
\text { of } \\
\text { c.c. }\end{array}$} & \multicolumn{3}{|c|}{ High speed steels } & \multicolumn{3}{|c|}{ Tool steels } & \multirow{2}{*}{$F_{0}$} & \multirow{2}{*}{$F$-table } \\
\hline & & & $N$ & $\sqrt{V}$ & $\phi$ & $N$ & $\sqrt{V}$ & $\phi$ & & \\
\hline $\begin{array}{l}\mathrm{C} \\
\mathrm{S} \\
\mathrm{Si} \\
\mathrm{Ni} \\
\mathrm{Mn} \\
\mathrm{Cu} \\
\mathrm{N} \\
\mathrm{Mo}\end{array}$ & $\begin{array}{l}0.33 \sim 1.44 \\
0.004 \sim 0.017 \\
0.14 \sim 0.53 \\
0.038 \sim 0.10 \\
0.15 \sim 0.48 \\
0.022 \sim 0.078 \\
0.010 \sim 0.042 \\
0.035 \sim 0.86\end{array}$ & $\begin{array}{c}76.2 \\
2960 \\
185 \\
549 \\
165 \\
718 \\
410 \\
(49.8) * *\end{array}$ & $\begin{array}{r}12 \\
10 \\
14 \\
9 \\
14 \\
9 \\
10 \\
9\end{array}$ & $\begin{array}{l}0.010 \\
0.0005 \\
0.006 \\
0.001_{2} \\
0.008 \\
0.001_{3} \\
0.0024 \\
0.015\end{array}$ & $\begin{array}{r}10 \\
8 \\
12 \\
7 \\
12 \\
7 \\
8 \\
6\end{array}$ & $\begin{array}{r}10 \\
6 \\
10 \\
8 \\
7 \\
6 \\
8 \\
10\end{array}$ & $\begin{array}{l}0.013 \\
0.0006 \\
0.004 \\
0.0016 \\
0.009 \\
0.0009 \\
0.003_{1} \\
0.00_{9}\end{array}$ & $\begin{array}{l}8 \\
4 \\
8 \\
6 \\
5 \\
4 \\
6 \\
7\end{array}$ & $\begin{array}{l}1.81 \\
1.47 \\
2.04 \\
1.83 \\
1.52 \\
2.08 \\
1.65 \\
2.74\end{array}$ & $\begin{array}{l}F(10 \%)=2.38 \\
F(25 \%)=1.66 \\
F(10 \%)=2.50 \\
F(10 \%)=2.83 \\
F(25 \%)=1.54 \\
F(10 \%)=3.98 \\
F(25 \%)=1.78 \\
F(10 \%)=2.83\end{array}$ \\
\hline
\end{tabular}

* Reading $/ \%$ ** Gradient of the regression line in trace range

じである、補正係数の有效数字は目標許容差を定量元素含 有率 $0.0 x \%$ に対し $0.001 \%$ ０.00x\%に対し $0.0001 \%$ とし $\tau^{(8)}$ ，妨害元素濃度が最高の值を基準として決定した．従 って，工具鋼におけるコバルト等の影響は関俰ないるのと し， 2 元系試料の結果は, 高速度龬のコバルト等の補正係 数算出のための情報として使われた.

以上の結果上り補正值を計算し，工具鋼と高速度鋼の標 準試料より，多項式近似で検量線の式を求めた。それぞれ の不偏分散 $(V)$ を算出し，不偏分散の比 $\left(F_{0}\right)$ こり，耐者の 分散の違いについて $F$ 検定を行った ${ }^{(12)(13)} . F$ 表より求め た $F_{0}$ に近い值を Table 2 に示した。いずれの場合も，有

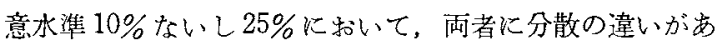

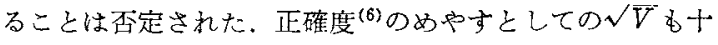
分小さく満足すべき值である。

使用した標潐試料は，特記しない限り，工具鋼はJSS 600 605-1，6の 12 個，高速度鋼は JSS 606〜611-3，5(610 は高炭素含有のため除く $\left.{ }^{(2)}\right)$ 和よび NBS SRM D 837，838， 840,841の計 14 個である。

炭素の場合は，600，604-1 は除外した。

硫黄は標準試料が硫化マンガンによる扁析のため，精度 が悪いので(2)，高周波溶解遠心鋳造試料を用いた。工具鋼 はJSS 600-5, 6, 602-1, 5, 604-1, 605-60計 6 個を用い た. 603 と605 は検量線上に乗らない場合が多かった。高 速度鋼は JSS 606-1，607〜611-2，特よび JSS 606〜611-5 (いずれも610を除く)の計 10 個である。

ニッケルは, JSS 606〜611-3 が表示傎に問題があり ${ }^{(2)}$, 除外し，再溶解試料 JSS 607〜611-6を追加した。

マンガンは，604-1 が異常値を与充除外した。

銅の場合は, JSS 600〜605-1 と JSS 606〜611-3 が表示 值に開題が考克られ採用しなかった。高速度鋼はJSS 607 〜611-6の再溶解試料を追加した。

窒素の場合は，高速度鐦として JSS 606～611-5 と再溶 解試料 JSS 606〜611-5(0.3\%A1 脱酸)を用いた。なお， 脱酸剤を加えない再溶解試料は低值を示した。工具鋼とし ては, JSS 601〜604-6 と再溶解試料 (600-6 を2 個, 601-5,
603-3)を用いた。この分析においては，工具鋼で作成した 検量線の外插点で高速度鈴を定量し，補正係数を算出した ため，正確さが劣ることが考えられる。

モリブデンの場合は，高速度鋼としてはモリブデン含有 量の低いJSS 606〜608-3，5 と再溶解試料 JSS 607, 608-6 および NBS SRM D 841 を用いた。工具鋼はJSS 604 は 含有量が多く除外した。 また，検量線用試料が不十分のた め, Fe-Mo 系標準試料 JSS FXS 344，345を追加して検 量線を作成した。検量線の式は 2 次式のため, 公配は微量 域の 1 次回帚式の勾配を示してある。

以上の他，本測定条件で記録計をオーバーした試料が除 外されている。

\section{VIII。結喜}

(1) 徽量元素 $(\mathrm{N}, \mathrm{S}, \mathrm{C}, \mathrm{Mo}, \mathrm{Si}, \mathrm{Ni}, \mathrm{Mn}, \mathrm{Cu})$ 定量のための 工具鋼と高速度鋼の検量線の1元化を試みた。

（2）近接線の影響の補正式は，工具鋼は鉄基 2 元系試料 で，高速度鋼は多元系試料を用いて求めることが出来る。

（3）高涑度鋼の補正俰数を，重回㷌分析で求める方法を 検討し，良讬な結果を得た。

(4) 測定感度と補正係数の間に双曲線の関係があること を見出した。

（5）測定感度が高いほど，補正係数の変化は小さく，測 定感度が低い汪ど，妨害元素の数は減る。

（6）工具鎆では宸素量 $0.2 〜 1.4 \%$ において影響はなか った。

（7）工具鋼は鉄基 2 元系試料で，高速度鋼は重回烧分析 で補正保数を算出した。

(8) 工具鋼と高速度鋼を統一検量線で分析し $F$ 検定し た結果，両者の分散に差があるとは言えないと結論され た。正確度も十分満起すべさ値を示した。

終りに，重回州分析のプログラム作成に際し，御指導頂 いた電子計算室の栗原 豊主任研究官に深く感謝の意を表 します。

玉た，東海大学工学部工業化学科 大久保 昭氏に実験 の御協力を頂き，御礼申し上げます。 


\section{文献}

（1）大河内春乃，高橋且征，鉿木俊一，須藤恵美子：日 本金属学会誌, 44(1980), 324 .

（2）大河内春乃，高橋且征，鉿朴俊一，須藤恵美子：日 本金属学会誌, 44(1980), 331 .

（3）井樋田 㓐，敒藤利光：鉄と鋼，66(1980)，1718.

（4）遠藤芳秀，杉原孝志，斉藤答二，松村泰治：鉄と鋼 65(1979), 1774 .

（5）大河内春乃, 高橋且征，鈴木俊一，佐藤幸一，須藤 患美子：日本金属学会誌，41(1977)，492.

(6) 高張友夫, 山本佳博, 山藤嘉久：鉄と銅,62(1976), 238 .
（7）田中 勇, 佐藤公隆, 松本龍太郎：分析化学, 24 (1975), 423.

（8）井樋田 睦，河島磯志：鉄と錩，60(1974)，1752.

(9) 萩原 卓, 樽木来俊，田中清之: 分光研究，15 (1966), 1 .

(10) A.N.Zaidel, V.K.Prokof'ev, S.M.Raiskii, V. A. Slavnyi and E. Ya. Shreider : Table of Spectral Lines, IFI/PLENUM, (1970).

(11) R. L. Kelly : Vacuum Ultravioret Emission Lines (Below 2000 $\AA$ ).

（12）大河内春乃，高橋且征，鈴木俊一，須藤患美子：日 本金属学会誌，42(1978)，409.

(13) 大河内春方，高橋且征，鉿木俊一，佐藤幸一，須藤 恵美子：日本金属学会誌，43(1979)，146. 